\title{
New Public Management And Service Science: Preparing Students For The $21^{\text {st }}$ Century
}

Michael O. Adams, Texas Southern University, USA Linda D. Smith, Texas Southern University, USA

\begin{abstract}
This effort will seek to discover the foundations of public management and how it relates to information technology, specifically understanding E-government and other technologies in the public domain. Public Management is the development or application of methodical and systematic techniques, often employing comparison quantification, and measurement, that are designed to make the operations of public organizations more efficient, effective and increasingly responsive. This is a considerably crisper, concise, and narrow definition compared to other definitions of public administration, and its sharper focus is attributable to the larger field's encompassing of values in addition to those of efficiency, effectiveness and responsiveness.
\end{abstract}

Keywords: New Public Management, E-Government Act 2002, Information Diffusion, Digital Divide

\section{INTRODUCTION}

$\mathrm{n}$ the past two decades, the subject of e-government has been given a great deal of attention. Previously, most research sought to define e-government and an overwhelming majority determined the term as being broadly defined as the use of information and communication technologies in the field of government. In order to better understand e-government studies, many researchers have used content analysis of egovernment-specific research. Most analytical approaches examined the following aspects: outlooks on the impacts of e-government, research philosophy, methods and techniques, and practical recommendations. The recent trend in e-government studies seeks to assess the development of e-government. Researchers hypothesize that e-government implementation is the result of New Public Management (NPM) and ultimately NPM seeks to make government more efficient. Pressures from public managers attempting to solve problems and from constituents, corporations, and others, attempting to control the actions of public managers have all influenced the promotion of e-government. The aforementioned influences are related to performance and accountability, and have correspondingly promoted change in Public Administration theory, implementation, and use of e-government initiatives. Most importantly, they have ignited continual increases of technology in government initiatives and have also created a push for efficiency in the public sector.

\section{METHODOLOGY}

In compliance with the New Public Management school of thought, e-government initiatives seek to make governmental transactions more consumer friendly, cost effective, and increase inter-organizational communication. Current analysis of e-government effectiveness has overlooked one of the most important components. Financial efficiency, as well as implementation have been greatly assessed while consumer advantage, has not been gauged. Ultimately, in order to better measure the effectiveness of e-government emphasis should not be on the shear numbers of usage but rather on access and quality of services. Analysis of e-government has a general scope of limitation to federal departments and programs. Since the staunch e-government initiative of 2002, numerous reports on implementation and funding have been conducted. However, quantitative and empirical research on efficiency and effectiveness is lacking. 


\section{FINDINGS AND ANALYSIS}

E-government arose from the idea of the ability to measure public sector productivity. This concept derives from public administration theory which in the United States began with President Woodrow Wilson who was the first to consider the science of public administration. In The Study of Administration Wilson wrote, "it is the object of administrative study to discover, first, what government can properly and successfully do, and, secondly, how it can do these proper things with the utmost possible efficiency and at the least possible cost either of money or of energy." Wilson embraced the concept of "reaching effective management by training civil servants and assessing their quality." This train of thought transitioned into the New Public Management Philosophy.

New Public management is an expansive and very complex term used to describe the upsurge of public sector reforms throughout the world since the 1960's. New Public Management is a management philosophy used by governments that encourages modernization and efficiency of the Public Sector. The main premise in the New Public Management reform movement is that more market orientation in the public sector will lead to greater costefficiency for governments, without having negative side effects on other objectives and considerations. The philosophy was to make the public system function equivalent to the private sector.

New Public Management, compared to other public management theories, is more oriented towards outcomes and efficiency through better management of public budget. It is considered to be achieved by applying competition, as it is known in the private sector, to organizations of public sector, emphasizing economic and leadership principles. New Public management addresses beneficiaries of public services much like customers as with the private sector and conversely citizens as shareholders. In relation to e-government there has been a rise in corporations seeking to provide the public sector with there technological needs. Since the e-government resolution, private companies have taken a vested interest in marketing to the public sector. Companies assert ability to offer the public sector technology solutions that that will enhance efficiency, communication and ultimately satisfaction.

E- Government, government's use of information technology to exchange information and services with citizens, businesses, and other branches of government, is regarded as a more efficient manner of managing the public sector. E-Government may be applied by the legislature, judiciary, or administration, in order to improve internal efficiency, the delivery of public services, or processes of democratic governance. E-government is often thought of as internet-based government however, many non-internet electronic government technologies can be used in this context. Some non-internet forms include telephone, fax, tracking systems, identity cards, smart cards and, polling station technology, Television and radio based delivery of government services, email, online community facilities, newsgroups and electronic mailing lists, etc. The most important anticipated benefits of egovernment include improved efficiency, convenience, and better accessibility of public services.

Research attests that E-government can only be as effective as the individuals administering. Theorist state that it is a mistake to focus computer systems, hardware, and software programs versus simple focusing on improved communications with citizens. Implementation of e-government can be risky, expensive, and challenging therefore, public managers must not only be technologically savvy but also possess leadership ability in order for egovernment to be effective.

President George W. Bush sent the following presidential memorandum July, $10^{\text {th }} 2002$ in regards to his proposed e-government initiative:

My administration's vision for Government reform is guided by three principles. Government should be citizencentered, results-oriented, and market-based. These principles have been woven into the five Government-wide reform goals outlined in my Administration's Management Agenda: strategic management of human capital, budget and performance integration, competitive sourcing, expanded use of the internet and computer resources to provide Government services (Electronic Government or E-Government), and improved financial management. Effective implementation of E-Government is important in making Government more responsive and cost-effective. 
Our success depends on agencies working as a team across traditional boundaries to better serve the American people, focusing on citizens rather than individual agency needs. I thank agencies who have actively engaged in cross-agency teamwork, using E-Government to create more cost-effective and efficient ways to serve citizens, and I urge others to follow their lead.

The E-Government Act of 2002 (H.R. 2458/S. 803) was signed by the President Bush on December 17, 2002. The Act establishes the Office of Electronic Government within the Office of Management and Budget. The goal is to establish policies that support information technology standards and guidelines and encouraging collaboration and enhancing understanding of best practices. The Act also seeks to strengthen information security government while authorizing of the Federal Information Security Management Act. The goals are to formalize the Federal Chief Information Officers Council and assign it as the primary interagency forum for improving agency practices related to the structure, development, acquisition, modernization, usability, function, sharing, and performance of government information resources. The office is also charged with creating an exchange program between technology workers in the public and private sector. The goals established in this Act demonstrate and undergirds the theoretical underpinnings of "New Public Management". The blending of training between public and private sector, the idea of establishing best practices, and the focus on financial efficiency are all examples of New Public Management.

Figure 1: HHS and EPA E-Payroll Processing Costs

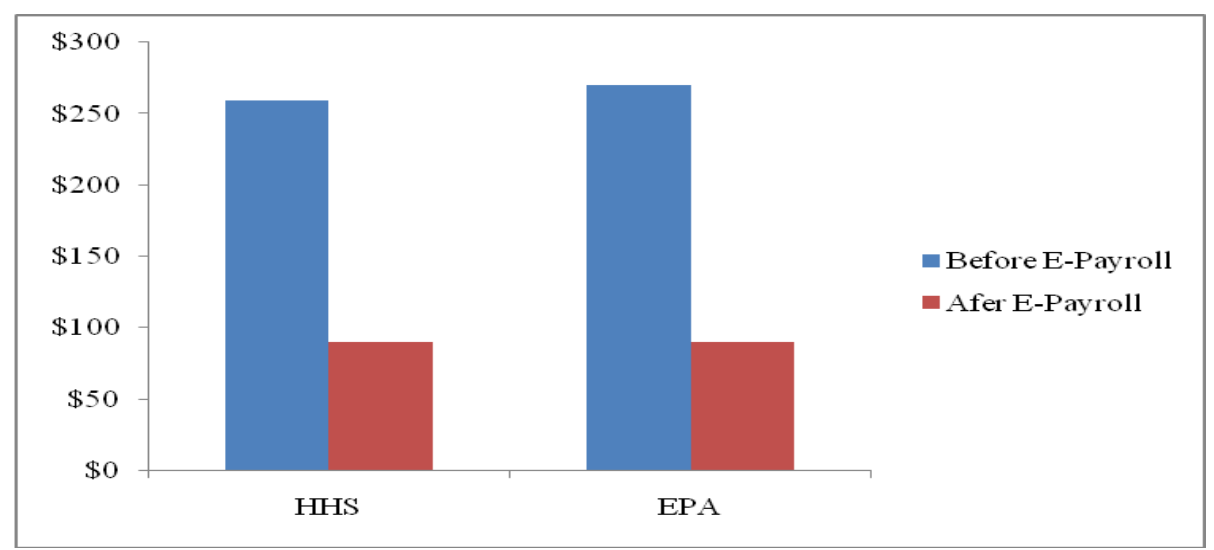

Source: FY07 Report to Congress on the Benefits of the E-Government Initiatives

Figure 1 demonstrates via e-payroll, cost savings and improved efficiencies are reported. For example, the Environmental Protection Agency has reduced the cost from $\$ 270$ to $\$ 90$ per employee for its staff of 18,000 which is an annual savings of approximately $\$ 3.2$ million.

The above data suggest that there has been a strong economic backing for developing and implementing egovernment. Fiscal Year 2007 e-government reports highlights usages of e -government. The report can be broken down into two domains inter-organization usage and consumer usage. The findings show that e-government has been used to make government as an organization more resourceful. Congruent with the private sector and society as a whole, government has incorporated e-training, e-travel, and e-commerce into its operation. The Department of Labor was one of the first agencies to complete its migration to an E-Travel service provider. They reported a decrease in travel voucher costs from approximately $\$ 60$ per voucher to approximately $\$ 25$ per voucher which was a decrease of about $60 \%$. Also, a reduction in voucher processing time was also observed. Additionally, the Department of Transportation and the Department of the Interior are each reportedly savings of over \$1 million per year through the use of online booking. The report states over 840,000 Federal employees have registered in the GoLearn.gov Learning Management System. Federal employees have completed more than 2.7 million courses 
provided through the E-Training initiative. E-Training is assisting the Federal government in maintaining a highly skilled workforce at a fraction of the cost of solely classroom training.

Figure 2: GoLearn.gov Registered Users Over Time

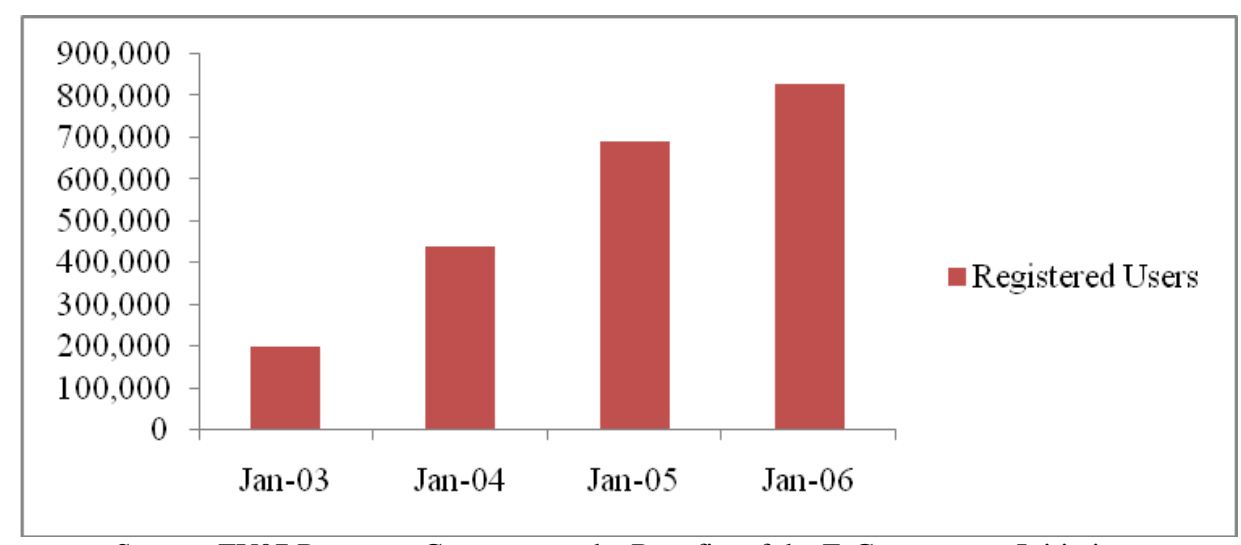

Source: FY07 Report to Congress on the Benefits of the E-Government Initiatives

Figure 2 reports the growth and expansion of continuing education amongst government employees. There has been about a 600,000 growth in GoLearn.gov users between January 2002 to January 2006.

Figure 3: Cumulative Number of Packages Posted by Quarter

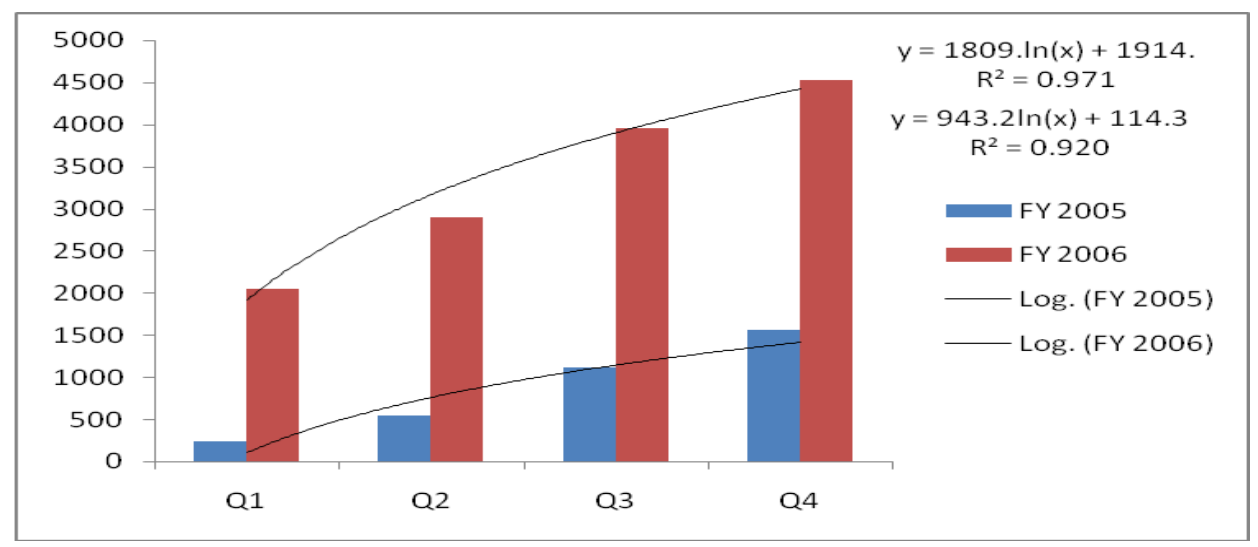

Source: FY07 Report to Congress on the Benefits of the E-Government Initiatives

Figure 3 references Grants.gov and the substantial increase in the number of grant application packages posted on Grants.gov since the beginning of fiscal year 2005 (FY05). In the first quarter of FY05, 252 packages were posted on Grants.gov. By the last quarter of fiscal year 2006 (FY06), 4,523 packages were posted on Grants.gov, almost 17 times the number at the beginning of FY05.

Although organization implementation and economic efficiency is important, meeting the consumer needs is of utmost importance. The FY07 reports document well document consumer usage. For example, GovBenefits.gov, which provides a single point of access for citizens to locate information and determine potential eligibility for government benefits and services, is receiving approximately 300,000 visits per month by citizens. 
For the 2006 filing season, the Internal Revenue Service received more than 3.9 million tax filings using the Free File E-Government solution. What these reports fail to observe is the consumer which consumers, and consumer needs are not being met by e-government. Also, as with previous research, it fails to present challenges of e-government.

There are many considerations and potential drawbacks of administering and designing e-government that have not been thoroughly analyzed. These include impacts on economic, social, and political factors, and disturbances to regularities by switching over systems. The development and implementation of e-government involves consideration of its effects on the organization of the public sector and on the nature of the services provided by the state including environmental, social, cultural, educational, and consumer issues.

Due to the views of citizens as customers, social equity is embraced in New Public Management. Thus, governments may need to consider the impact by age, language skills, educational level, and accessibility, amongst other factors creating a technological gap commonly known as "Digital Divide". Economic factors are the leading causes in creating a digital divide, or the effect of non-use, non-availability or inaccessibility of e-government, or of other technological resources, upon the structure of society, and the potential impact on income and economics. In reality, many of governmental departments serve citizens who are impacted by the lack of technological resources. Government services including housing, food, and health have all embraced e-government by providing on-line services and documents. It is pivotal that when implementing e-government to ensure all citizens are capable of being serviced rather than causing disenfranchisement of individuals who don't have equal technological access or education.

Figure 4: Proportion of Adults (age 25+) that Have Computer by Education and Race Current Population Survey, 1997-2005

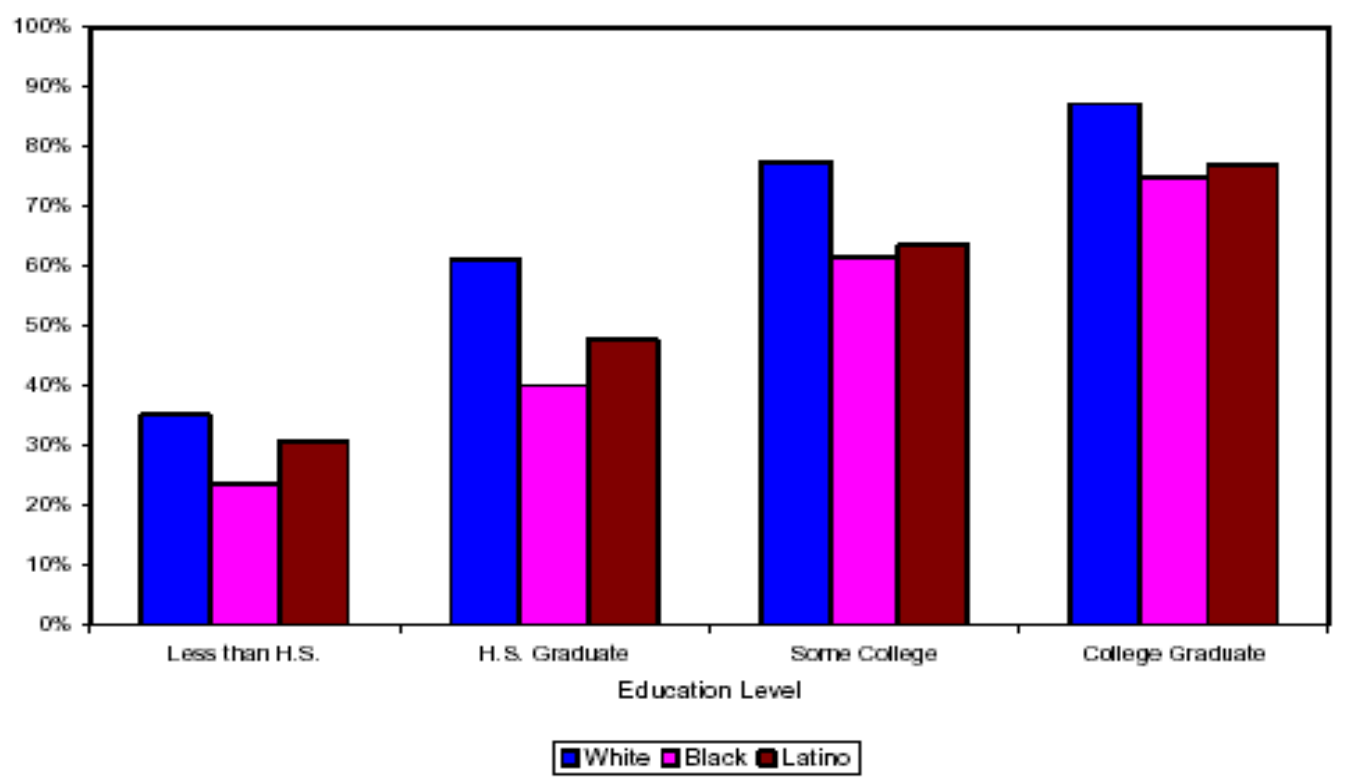

Source: http://www.freepress.net/docs/lccrdigitaldivide.pdf 10/20/07

Figure 4 demonstrates that the high education correlates with home computer access. It also shows that within each education level, blacks and Latinos are less likely to own a computer than whites. 
Figure 5: Proportion of Adults (Ages 25+) that Have Home Computer by Education and Race Current Population Survey, 2005

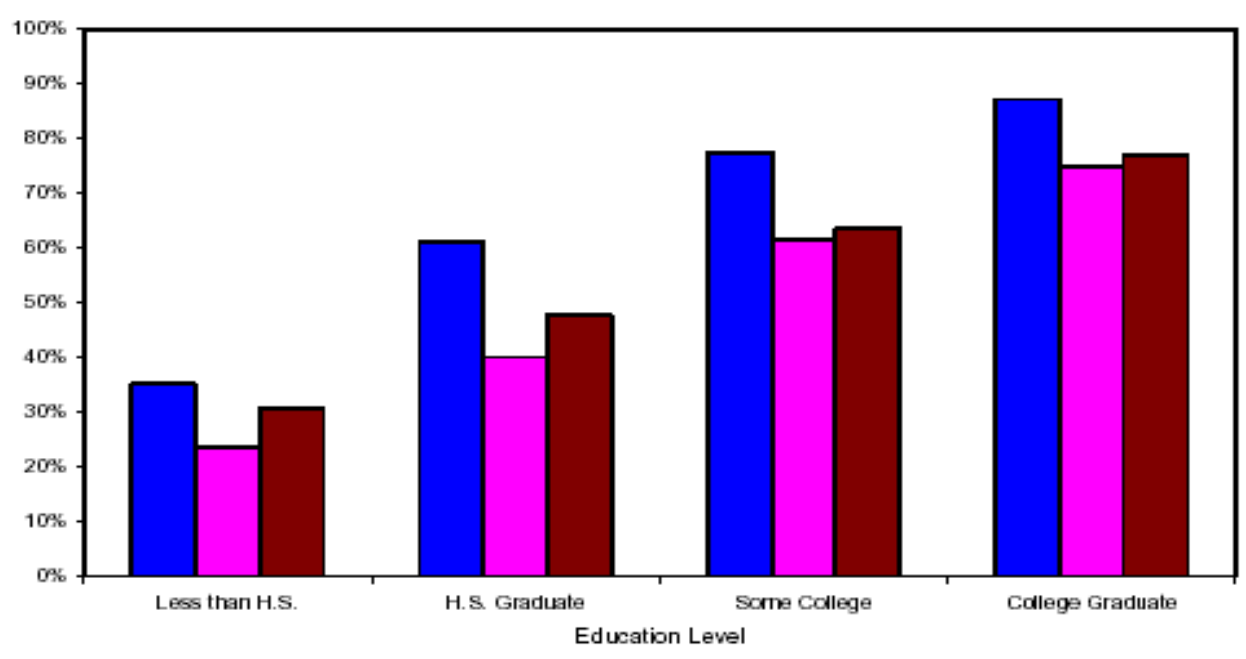

WWite QBlack QLatino

Source: http://www.freepress.net/docs/lccrdigitaldivide.pdf 10/20/07

Figure 5 in comparison with Figure 4 shows that home computer ownership has risen mostly for those who have higher education levels. While the growth of computer ownership for those who have not completed high school have remained about the same. The data still shows minorities are less likely to own computers than their white counterparts with similar education levels.

Figure 6: Proportion of the Population (Ages 18+) Who Use the Internet at Home By Race/Ethnicity Current Population Survey, 1997-2005

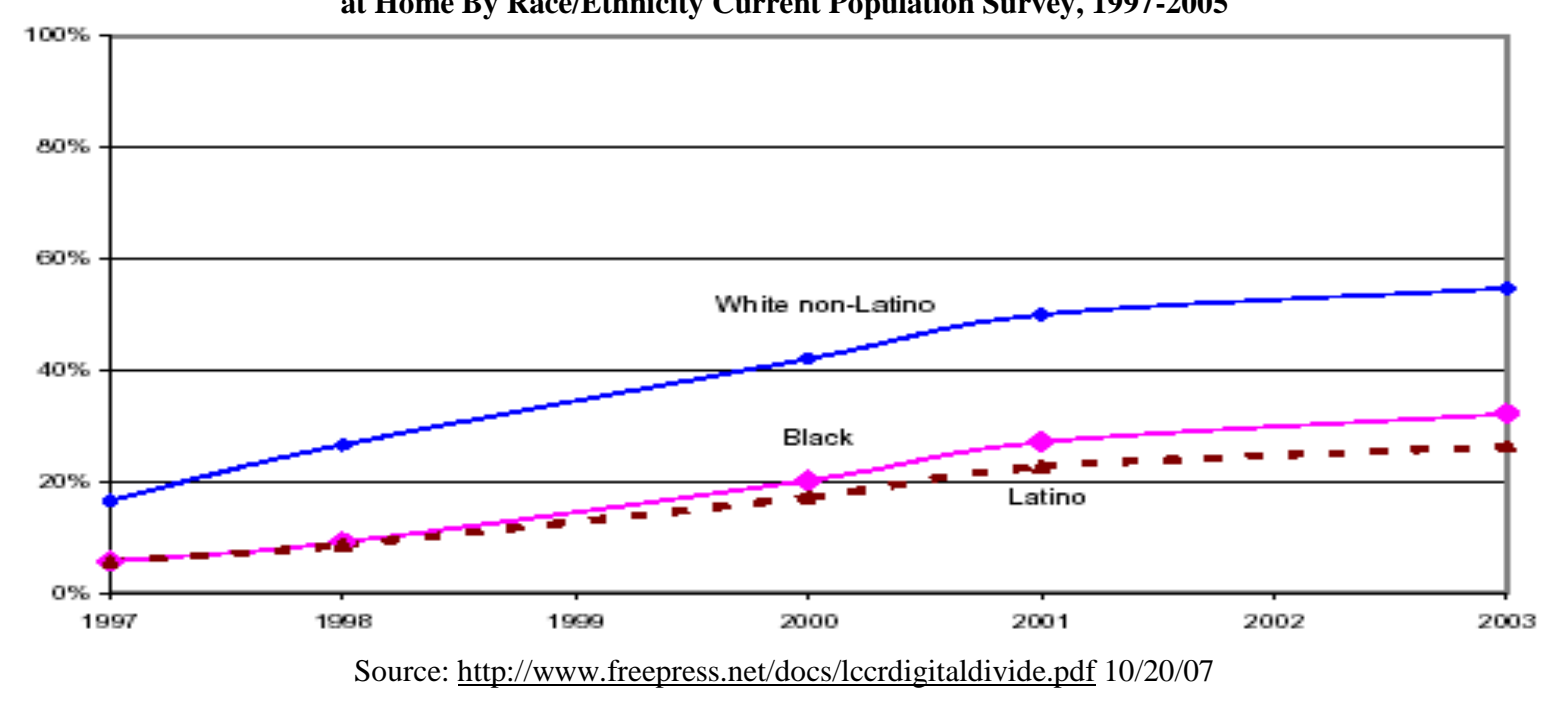

Figure 6 revels a widening of the gap between proportion of home internet use between whites and minorities especially Latinos. 
Figure 7: Proportion of the Population that Has Access to the Internet at Home by Income and Race Current Population Survey, 1997-2005

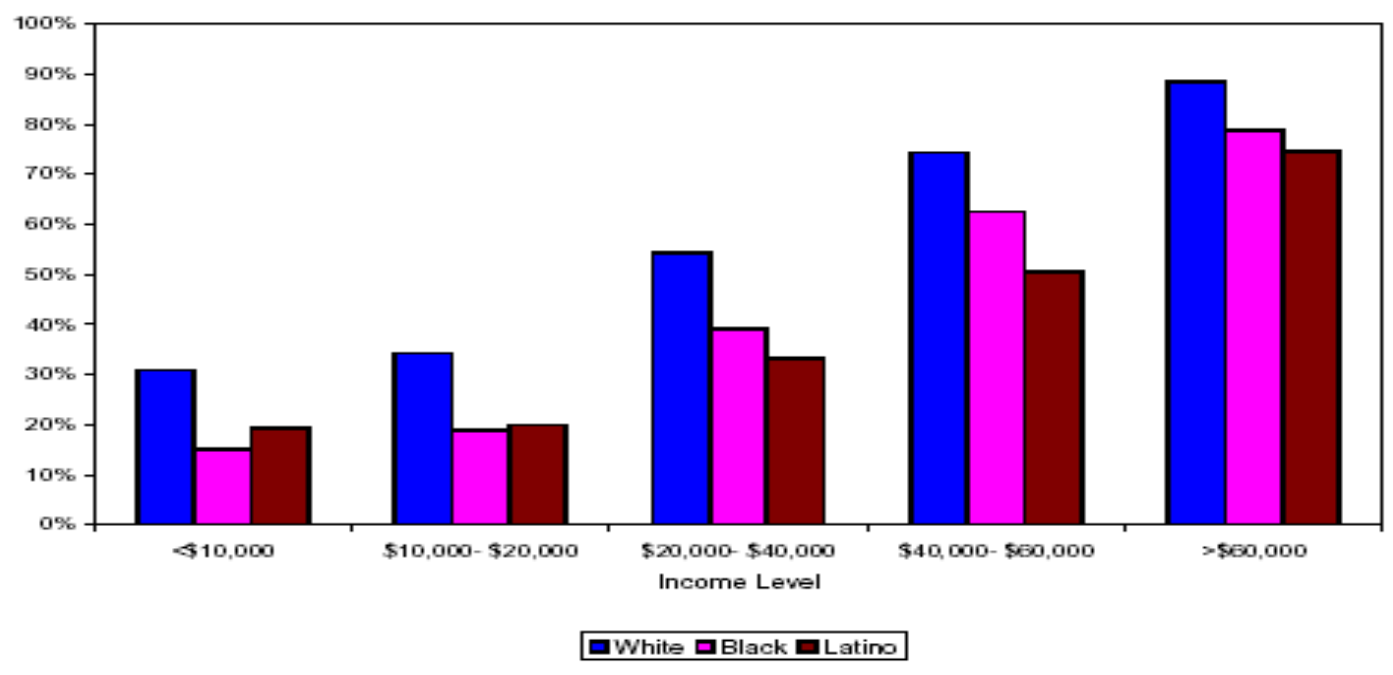

http://www.freepress.net/docs/lccrdigitaldivide.pdf 10/20/07

Figure 7 displays that income is directly related to internet access. The lower the income the less likely that the home is internet accessible. The graph also exhibits that within each income range, whites are more likely to have home access than minorities.

\section{CONCLUSION}

Ultimately, e-government seeks to more effectively serve the public. Since 2002, the focus on measuring effectiveness has been on usage of technology to deliver public serves as well as fiscal conservation. However, neither of these items empirically measure constituent advantage. Evaluations of how readily accessible, user friendly, and efficient e-government is to the consumer should be made versus just looking at these variable for governmental organizations. Although generated reports have suggested e-government is cost effect for the organization, little research has been done to examine if the implementation how costly this implementation is for citizens. Effective communication and dissemination of information is also vital in analyzing the successfulness of e-government. E-government can be perceived as providing expedited information to the public. However, may potentially come at the expense of limited effective personal communication. When consumers have difficulties, questions, or complications, e-government may present more of a challenge than a benefit. In summary, when evaluating the effectiveness of e-government, more focus should be directed towards the public versus governmental organizations. Real success is determined by the needs of the public being met effectively and efficiently.

\section{REFERENCES}

1. Analyzing e-government research: Perspectives, philosophies, theories, methods, and practice. By: Heeks, Richard; Bailur, Savita. Government Information Quarterly, 2007, Vol. 24 Issue 2, p243-265, 23p; DOI: 10.1016/j.giq.2006.06.005; (AN 24544192)

2. Applying participatory design and collaboration in digital public services for discovering and re-designing e-Government services. By: Anthopoulos, Leo G.; Siozos, Panagiotis; Tsoukalas, Ioannis A. Government Information Quarterly, 2007, Vol. 24 Issue 2, p353-376, 24p; DOI: 10.1016/j.giq.2006.07.018; (AN 24544198)

3. E-government research: Reviewing the literature, limitations, and ways forward. By: Yildiz, Mete. Government Information Quarterly, Jul2007, Vol. 24 Issue 3, p646-665, 20p; DOI: 10.1016/j.giq.2007.01.002; (AN 25410875) 
4. Personalization in the public sector: An inventory of organizational and user obstacles towards personalization of electronic services in the public sector. By: Pieterson, Willem; Ebbers, Wolfgang; van Dijk, Jan. Government Information Quarterly, Jan2007, Vol. 24 Issue 1, p148-164, 17p; DOI: 10.1016/j.giq.2005.12.001; (AN 23351162)

5. Strategic Management in Public and Private Organizations: Implications of Distinctive Contexts and Constraints Peter Smith Ring; James L. Perry The Academy of Management Review, Vol. 10, No. 2. (Apr., 1985), pp. 276-286.

6. Key Information Systems Management Issues for the Public Sector (in Application) Sharon L. Caudle; Wilpen L. Gorr; Kathryn E. Newcomer MIS Quarterly, Vol. 15, No. 2. (Jun., 1991), pp. 171-188.

7. Managerial Strategies in Municipal Government Organizations (in Research Notes) John M. Stevens; Robert P. McGowan The Academy of Management Journal, Vol. 26, No. 3. (Sep., 1983), pp. $527-534$.

8. A Critical Appraisal of the Study of Public Administration John D. Millett Administrative Science Quarterly, Vol. 1, No. 2. (Sep., 1956), pp. 171-188.

9. Science and the Public Sector: A National Policy Overview (in Symposium: From Knowledge to Action: Science and its Uses) M. Frank Hersman Proceedings of the National Academy of Sciences of the United States of America, Vol. 71, No. 6. (Jun., 1974), pp. 2565-2570.

10. Technology Diffusion and Public Policy aul Stoneman; Paul Diederen The Economic Journal, Vol. 104, No. 425. (Jul., 1994), pp. 918-930.

11. Are We Really a Nation Online? Racial and Ethnic Disparities and Their Consequences. Robert Fairlie, http://www.freepress.net/docs/lccrdigitaldivide.pdf accessed 10-01-2007

12. The Duality of Technology: Rethinking the Concept of Technology in Organizations Wanda J. Orlikowski Organization Science, Vol. 3, No. 3, Focused Issue: Management of Technology. (Aug., 1992), pp. 398427.

13. Policy on Dissemination of Federal Information Resources Updated (in The Profession) Michael Brintnall PS: Political Science and Politics, Vol. 26, No. 4. (Dec., 1993), p. 796.

14. Wilson, Woodrow. The Papers of Woodrow Wilson. 69 vols. Edited by Arthur S. Link. Princeton, N.J.: Princeton University Press, 1966-1994.

15. Report to Congress on the Benefits of the E-Government Initiatives http://www.whitehouse.gov/omb/egov/documents/FY07_Benefits_Report.pdf accessed 10-01-2007

16. Computer and Internet Use in the United States. U.S. Census report http://www.census.gov/prod/2005pubs/p23-208.pdf, accessed 10-01-2007

17. Report to Congress on the Benefits of the E-Government Initiatives http://www.whitehouse.gov/omb/egov/documents/FY07_Benefits_Report.pdf accessed 10-01-2007 